


\section{UNIVERSITY OF WASHIIVGTON \\ DEPARTMENT OF OCEANOGRAPHY \\ Seattle, Washington 98105}

Technical Reports

Nos. 142, 143, 144, 145, 146,

147, 148, and 149

A COMPILATION OP ARTICLES REPORTING RESEARCH

SPONSORED JOINILY BY

THE U.S. ATOMIC ENERGY COMMISSION

and

THE OFFICE OF NAVAL RESEARCH

U. S. Atomic Energy Commission

Contract AT(45-1) -1725 and

Office of Naval Research

Contracts Nonr-477(10) and Nonr-477(37)

Project NR 083012

Reference M66-2

January 1966
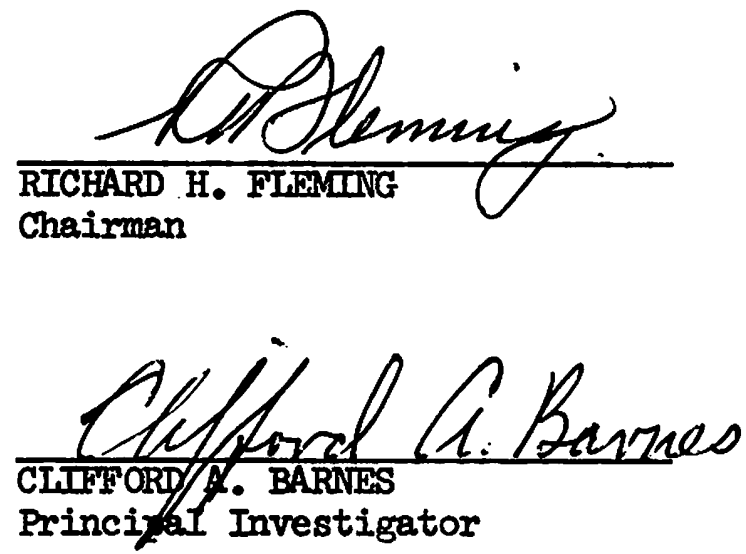

Reproduction in whole or in part is permitted for any purpose of the United States Government 
ARTICLES REPORTTNG RESEARCH SPONSORED JOTNTLY BY THE

U.S. ATOMIC ENERGY COMMISSION AND THE OFFICE OF NAVAI RESEARCH

Technical Report No. 142

BIO-LITHOIOGY OF NORTHEAST PACIFIC SURFACE SEDTMENTS, by Y. R. Nayudu and B. J. Enbysk. Marine Geology, 2(4):310-342. 1964. (AEC: RLO-1725-42)

Technical Report No. 143

THE TINTINNID PARAFAVELIA GIGANTEA (BRANDT), KOFOID \& CAMPBELL, 1929, IN THE NORTH PACIFIC OCEAN, by Hsin-Yi Ling. Journal of Paleontology, 39(4): 721-723. 1965. (AEC: RL0-1725-43)

Technical Report No. 144

THE CARBONATE CONTENT OF SURFACE SEDTMENTS FROM THE NORTHEAST PACIFIC OCEAN, by M. Grant Gross. Northwest Science, 32(3):85-92. 1965. (AEC: RLO-1725-44)

Technical Report No. 145

RADIOACTIVITY OF THE COLUMBIA RIVER EFFLUENT, by M. Grant Gross, Clifford A. Barnes, and Gordon K. Riel. Science, 149(3688):1088-1090. 1965. (AEC: RLO-1725-45)

Technical Report No. 146

FRACTIONATION OF PHYTOPLANKTON COMMUNITIES OFF THE WASHINGTON AND OREGON COASTS, by George C. Anderson. Limnology and Oceanography, 10(3):477480. 1965. (AEC: RLO-1725-46)

Technical Report No. 147

CHLOROPHYLLS IN MARINE PHYTOPLANKTON: CORRELATION WITH CARBON UPTAKE, by G. C Anderson and K. Banse. Deep-Sea Research, 12(4):531-533. 1965. (AEC: RLO-1725-47)

Technical Report No. 148

GRAPHIC REPRESENTATION OF THE SALINITY DISTRIBUTION NEAR THE COLUMBIA RIVER MOUTH, by Betty-Ann Morse and Noel McGary. Pp. 923-942 in Ocean Science and Ocean Engineering 1965, vol. 2. Marine Technology Society, Washington, D. C. 1965. (AEC: RLO-1725-3)

Technical Report No. 149

THE UNION OF THE COLUMBIA RIVER AND THE PACIFIC OCEAN -- GENERAL FEATURES, by Alyn C. Duxbury. Pp. 914-922 in Ocean Science and Ocean Engineering 1965, vol. 2. Marine Technology Society, Washington D. C. 1965. (AEC: RLO -1725-5) 
UNIVERSITY OF WASHINGTON

DEPAITTMENT OF OCEANOGRAPHY

TECHNICAL REPORT NO. 145

\title{
Radioactivity of the Columbia River Effluent
}

\author{
M. Grant Gross \\ Clifford A. Barnes \\ Gordon K. Riel
}




\section{Radioactivity of the Columbia River Effluent}

Abstract. Chromium-51 and zinc-65 were detected as far as 115 and 15 kilometers, respectively, from the mouth of the Columbia River; zinc-65 also was found at a few isolated stations: Zirconium-95 and niobium-95 from atmospheric fallout occurred in the river effluent but they were most abundant in surface waters further offshore. Distribution of the radionuclides is controlled largely by surface currents and by upwelling of sea water near the coast.

Surface sea waters near the Washington-Oregon coast contain radionuclides derived from the reactors at Hanford, Washington $(1,2)$, making possible the study of the dispersal of Columbia River water at sea and the behavior of various radionuclides in the marine environment. Radionuclides from the Columbia River are distinctly different from those naturally present in sea water or in marine sediments (3) or from fission products derived from worldwide atmospheric fallout (4).

During Brown Bear cruise 331, 1324 August 1963, radioactivity of surface sea water near the mouth of the Columbia River was measured in situ at stations where the salinity, temperature, and dissolved oxygen content were determined from samples of surface water. Gamma-ray spectra (Fig. 1) of the surface waters (approximately $3 \mathrm{~m}$ deep) were obtained with an underwater scintillation detector (5) consisting of a $12.5-\mathrm{cm}$ by $15-\mathrm{cm}$ crystal of NaI (Tl) optically coupled by a lucite light-pipe to a photomultiplier tube. The instrument, enclosed in a steel pressure housing, was lowered by an armored, single-conductor, coaxial cable which connected the detector system to the high-voltage supply, a multichannel spectrum analyzer. and other electronic equipment aboard ship. To prevent contamination by absorption of radioactive materials, the outer surface of the pressure housing was cleaned with solvent and coated with waterproof grease at each station immediately before the probe was lowgamma-ray activity.

Unfortunately, radiochemical analyses of sea-water samples taken during the cruise failed: thus identification of radionuclides in the waters is based on the photopeak energies in the spectra. Because the sources of the radioactivity are known to be the Columbia River, worldwide fallout, and naturally occurring radionuclides, our identification of the radionuclides was greatly simplified (6).

The Columbia River discharge forms a plume of surface water with salinity intermediate between the negligible salt concentration of the river water and that of the ambient sea surface, which is variable but generally slightly greater than 32.5 per mil. The salinity of the surface waters increases with distance from the river mouth along the axis of the plume and laterally away from the axis. Most of the low-salinity water from the river remains within $40 \mathrm{~m}$ of the surface. The effluent, with salinity less than 32.5 per mil, moves generally southwestward during the summer months and may extend south of $40^{\circ} \mathrm{N}$ during September and October, the period of its maximum detectable spread (7).

The core of the plume during August 1963 is outlined by the 31-per-mil isohaline (Fig. 2). Surface waters of variable salinity, generally less than 30 per mil, occurred within approximately ered; the grease had no detectable
$60 \mathrm{~km}$ of the river mouth where the water from the river and sea initially mix (7). Upwelled water, recognized by high salinities and low concentrations of dissolved oxygen, was present at or near the surface just south of the river mouth and in the inshore area extending southward from Tillamook Head.

Chromium-51 (half-life, 28 days) from the Columbia River was detected in surface sea water over a large area (Fig. 2), with the highest activities in the river estuary. Within 15 to $40 \mathrm{~km}$ of the river mouth the activity of $\mathrm{Cr}^{\mathrm{in}}$ exceeded that of the naturally occurring potassium-40 in sea water. Chromium-51 was detectable in a band, generally parallel with the coast, up to $115 \mathrm{~km}$ south of the river mouth but only $25 \mathrm{~km}$ north and west of the mouth.

The concentration of $\mathrm{Cr}^{51}$ in the surface sea water decreases rapidly with distance from the mouth of the river mouth because of the mixing of river water with uncontaminated sea water, by radioactive decay of $\mathrm{Cr}^{51}$, and by any other process(es) that remove $\mathrm{Cr}^{51}$ from the surface layers, such as sedi-

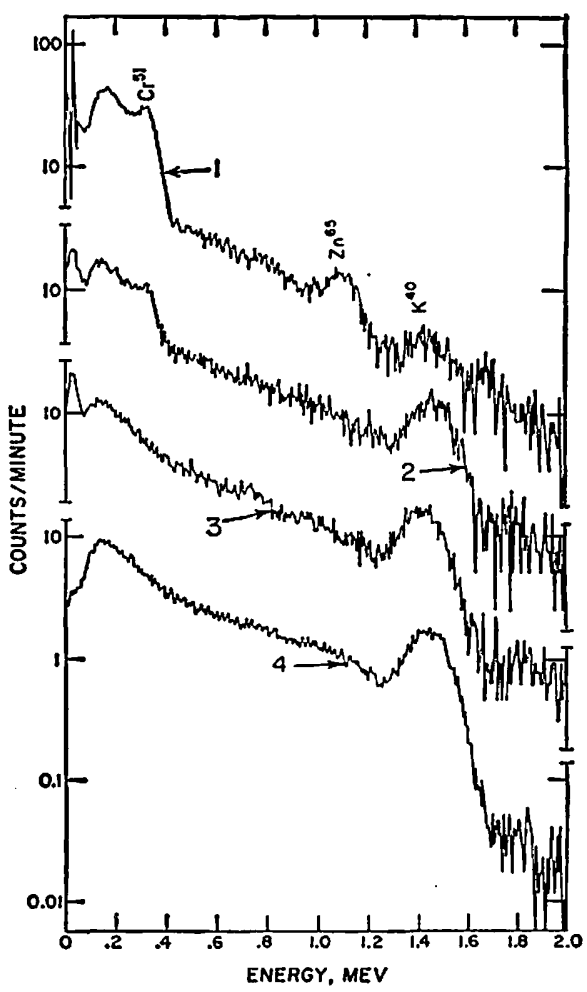

Fig. 1. Typical gamma-ray spectra obtained by the detector system. 1, Columbia River water, Astoria, Oregon, 14 August 1963. 2, Sea water; depth $3 \mathrm{~m}$; salinity, 22.35 per mil; 24 August 1963. 3, Sea water; depth, $3 \mathrm{~m}$; salinity, 30.56 per mil; 20 August 1963. 4, Sea water; depth, 190 m; salinity, 33.95 per niti: : 3 August 1963 . 
mentation of any particulate matter. South of Tillamook Head, the absence of $\mathrm{Cr}^{51}$ is due largely to upwelling, which keeps Columbia River water away from the coast.

Concentrations of zinc-65 (half-life, 245 days) were highest in the Columbia River estuary near Astoria, Oregon, and in surface sea water within approximately $15 \mathrm{~km}$ of the river mouth. It appears that $\mathbf{Z n}^{65}$ is rapidly removed from surface sea waters or diluted to such low concentrations that it cannot be used to trace the movement of river effluent. Zinc- 65 is detectable in planktonic marine organisms near the Columbia River (2). Three isolated occurrences of $\mathrm{Zn}^{65}$ detected during this survey may be due in part to marine organisms. Two of the three stations were occupied in the predawn hours when planktonic organisms are commonly near the surface.

Zirconium-95 and niobium-95 (halflife, 65 days) were ubiquitous in offshore surface waters but greatly reduced in concentration in surface waters within 30 to $60 \mathrm{~km}$ of the coast, except near the mouth of the Columbia River (Fig. 3); no other fission products were detected.

The distribution of these radionuclides is partly controlled by combined effects of the ocean currents near the coast and of the winds which cause the surface waters to move generally southwestward in late summer (7). The low-salinity, less-dense water formed by the effluent of the Columbia River tends to spread over the ambient waters in the coastal and offshore regions. Fronts characterized by surface confluence and sinking are particularly well defined at the boundary between the plume of river water and the upwelled waters near the Oregon coast where the upwelling is more or less continuous.

The upwelled water brought to the surface was previously offshore at depths of 100 to $200 \mathrm{~m}$ and shielded from recent atmospheric fallout. Consequently, upwelled coastal waters can be expected to have low concentrations of fallout nuclides with relatively short half-lives, such as $\mathrm{Zr}^{95}$ and $\mathrm{Nb}^{\mathbf{0 5}}$. In contrast, surface waters seaward of the plume zerain in the surface, windmixed, layer curing the warming part of the annual cycie, retaining the fallout nuclides above the seasonal pycnocline. Fallout radios mides brought into the ocean with Culimbia Rive: :ater probably remain in the less-dense, less-saline waters of the plume and also contribute to the general level of $\mathrm{Zr}^{95}$ and $\mathrm{Nb}^{95}$ activity in the surface waters.
These studies confirm the surface current patterns determined by standard oceanographic techniques (7) and demonstrate that where suitable radio-

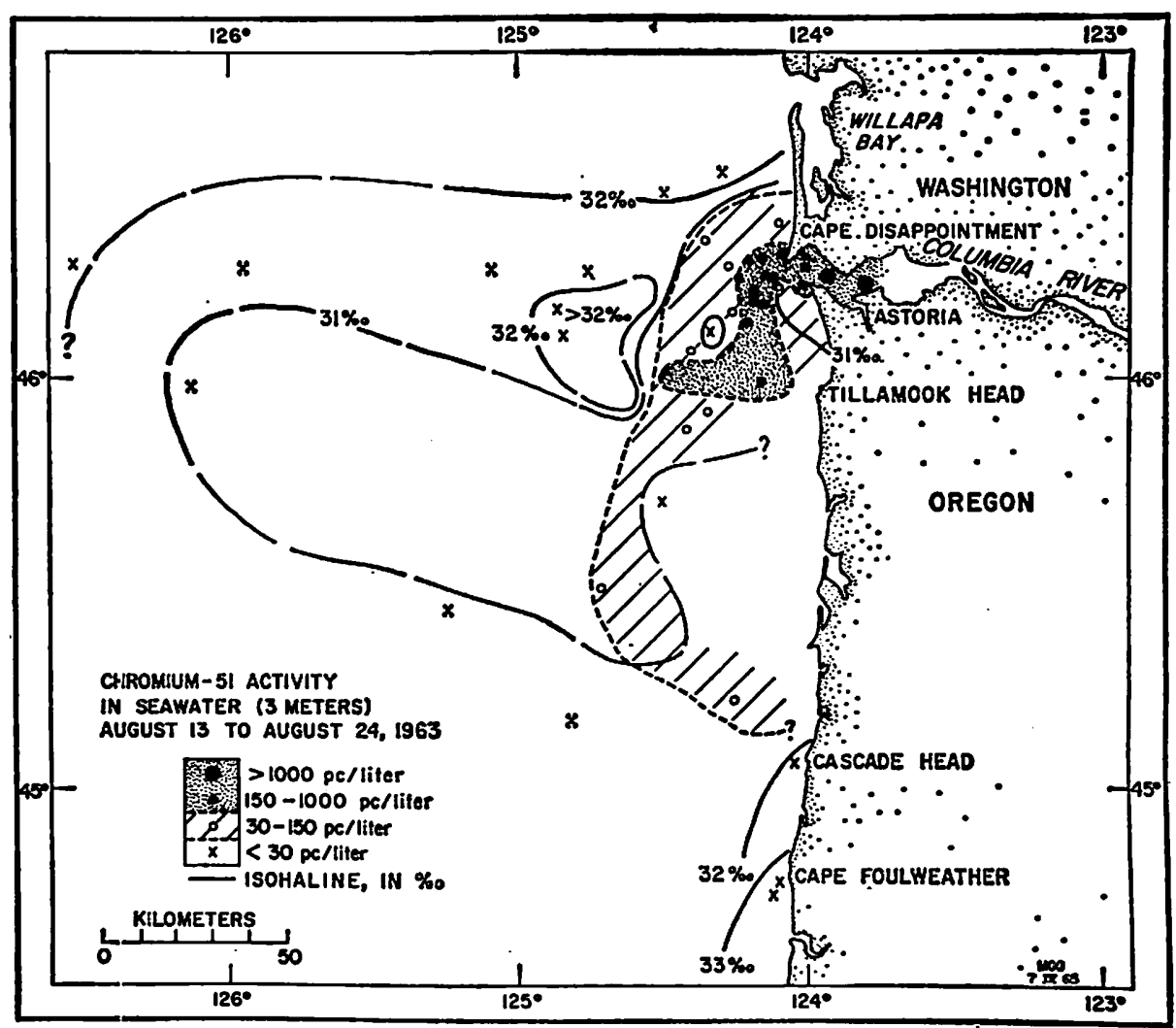

Fig. 2. Distribution of chromium-51 in sea water at a depth of $3 \mathbf{m}$.

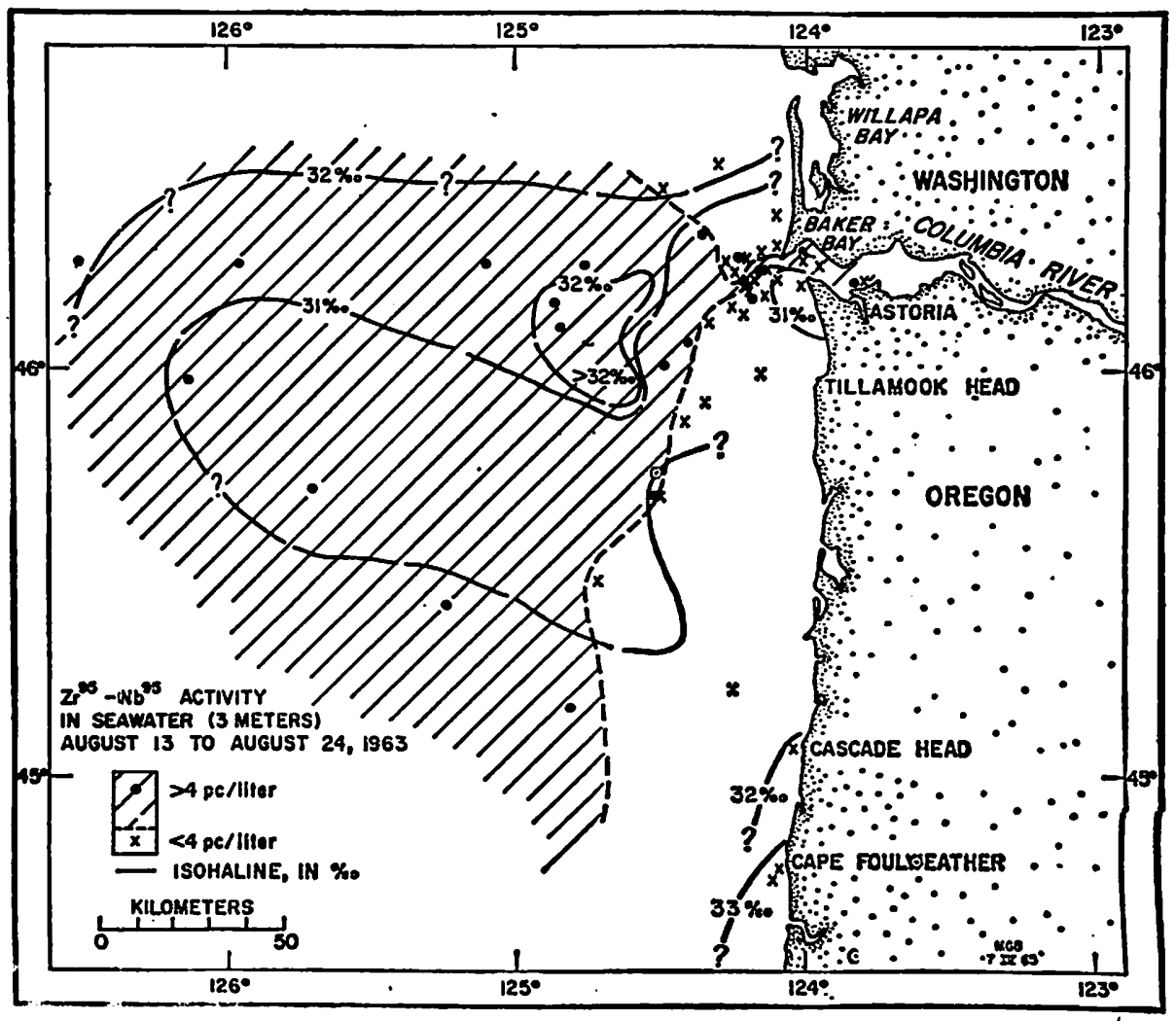

-ig. 3. Distribution of zirconium-95 and niobium-95 in sea water at a depth of $3 \mathrm{~m}$. 
nuclides are introduced into the ocean in large quantities they may be used to study local water circulation. Use of an in situ detector greatly simplifies the procedure and many more analyses can be made than would be possible if extensive radiochemical separations were required.

M. Grant Gross

Clifford A. Barnes

Department of Oceanography,

University of Washington, Seattle

GORDON K. RIEL

U.S. Naval Ordnance Laboratory, White Oak, Silver Spring, Maryland

\section{References and Notes}

1. Environmental Studies and Evaluation Group, Eialuation of Radiological Conditions in the Vicinity of Hanford for 1963, Publ. HW. 80991 (Hanford Atomic Products Operation, Richland, Wash., 1964).

2. C. Osterberg, J. Pattullo, W. Pearcy, Limnol. Oceanog. 9, 246 (1964).

3. F. F. Koczy and J. N. Rosholt, in Nuclear Radiation in Geophysics, $\mathrm{H}$. Israel and A. Krevs, Eds. (Academic Press, New York, 1962), p. 18 .

4. J. Z. Holland, Federation Proc. 22, 1390 (i963).

5. G. K. Riel, Electronics 36(10), 56 (1963).

6. The data were analyzed by a spectrum-stripping technique in which the total number of counts in the photopeak of each radionuclide was corrected by subtracting the counts due to Compton scattering associated with photopeaks of higher energy. The concentration of each radionuclide was calculated after determining the efficiency of the detector by measuring its response in $10^{5}$ liters of various measuring its response in $10^{5}$ liters of various
solutions containing known concentrations of solutions containing known concentrations of
$\mathrm{Cr}^{31}$. $\mathrm{Cs}^{197}, \mathrm{La}^{140}$, and $\mathrm{K}^{10}$. The efficiency for $\mathrm{Zr}^{00}-\mathrm{Nb}^{05}$ and $\mathrm{Zn}^{0 \mathrm{~s}}$ was estimated by interpolation on a plot of detector efficiency as a function of the photofraction of the crystal, divided by the square of the mean free path in water of the gamma photon. The data, computed as picocuries per liter for each radionuclide, are considered significant if the activity was greater than two standard deviations estimated from the counting statistics. Zirconium-95 and $\mathrm{Nb}^{\mathrm{B}}$ were ubiquitous in the surface waters, so spectra obtained in the upwelled coastal waters were arbitrarily taken as background. Subsequent analysis of the spectra used to obtain the correction for the Compton effect indicates that these waters contained $\mathrm{Zr}^{0.5}+\mathrm{Nb}^{0 \mathrm{i}}$ at 3 to $4 \mathrm{pc} /$ liter.

7. T. F. Budinger, L. K. Coachman, C. A. Barnes, "Columbia River effluent in the northeast Pacific Ocean, 1961, 1962: Selected aspects of physical oceanography," Dept. of pects of physical oceanography," Dept. of Tech. Rept. 99 (February 1964).

8. We thank A. H. Seymour and D. E. Engstom, Laboratory of Radiation Biology, and R. Pedrick, U.S. Naval Oceanographic Office, for assistance. Dick Duffy, Department of $\mathrm{Nu}$ clear Engincering, University of Maryland, assisted in the design and construction of the in sitl gamma-ray detector. Studies conducted in a cooperative program with the Laboratory of Radiation Biology, University of Washing. ton. Supported by AEC contract AT(45-1)1725 and by ONR contracts Nonr-477(10) and 477(37) project NR 083012 Contribution No. 344, Department of Oceanography, University of Washington.

6 July 1965 